\title{
Fotografia: Grupa polskich studentów i stypendystów. Getynga, lato 1907. Trudne identyfikacje
}

\author{
A Group of Polish Students and Scholarship Holders. \\ Göttingen, Summer of 1907: A Photo. Difficult \\ Identifications
}

The article was inspired by a group photo of twelve young Polish scientists, taken in the summer of 1907 in Göttingen. Some of the men portrayed in it - then still scholarship holders and students - gained worldwide fame a few years later, and almost all of them became famous scientists in pre-World War II Poland. The original of the photo, ref. no. ZF.263, was stored in the Archives of Polish Mathematicians in Sopot and is currently in the Central Mathematical Library of the Institute of Mathematics of the Polish Academy of Sciences (CBM IMPAN) in Warsaw. This photograph is a valuable memento for the history of Polish science. The article aims to reestablish the actual faces and names connection of the people in the photo since even renowned experts in photography had problems with their proper identification. The text gives examples of publications with a reproduction of the photo ZF.263 (or part of it) where some people are identified incorrectly.

Keywords: Georg August University of Göttingen, Polish students in Germany in the $19^{\text {th }}$ and $20^{\text {th }}$ centuries, Tadeusz Banachiewicz, Wacław Dziewulski, Władysław Dziewulski, Jan Kroo, Felicjan Kępiński, Stanisław Kępiński, Antoni Przeborski, Julian Przedborski, Wacław Sierpiński, Hugo Steinhaus, Leo Schultz

Słowa kluczowe: Uniwersytet Georga-Augusta w Getyndze, Polacy na studiach w Niemczech w XIX i XX w., Tadeusz Banachiewicz, Wacław Dziewulski, Władysław Dziewulski, Jan Kroo, Felicjan Kępiński, Stanisław Kępiński, Antoni Przeborski, Julian Przedborski, Wacław Sierpiński, Hugo Steinhaus, Leo Schultz

Problem badawczy

Problem zamiany oblicza tylko z pozoru jest błahą ciekawostką, daleką od pól badawczych historyków nauki. Tymczasem w rzeczywistości interesują się oni ilustracjami z epoki i chętnie po nie sięgają, gdyż dodają one atrakcyjności artykułom i książkom. Na po- 

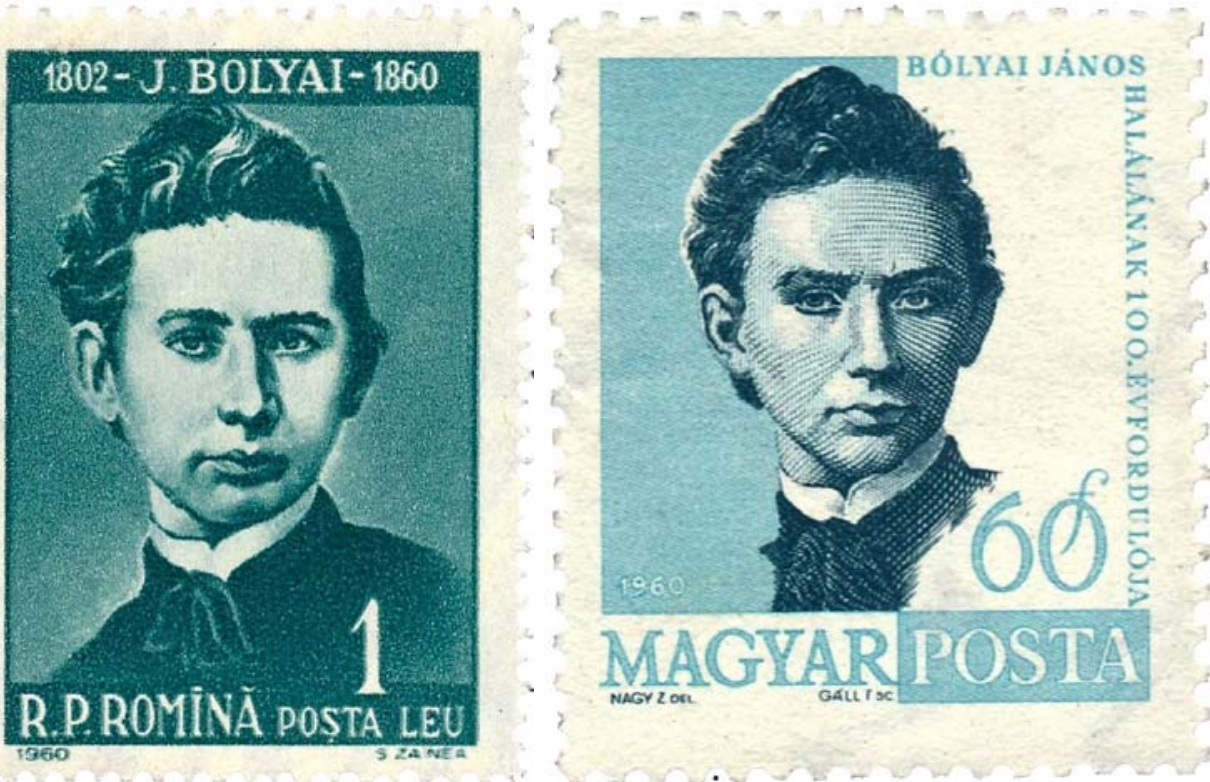

Ryc 1. Kopie znaczków z podobizną Jánosa Bolyaia; z lewej strony rumuński, z prawej węgierski (z kolekcji znaczków matematycznych Danuty i Krzysztofa Ciesielskich).

czątku XXI w. matematyków, fizyków i historyków nauki żywo zainteresowała „sprawa Legendre'ów". Okazało się bowiem, że wielokrotnie publikowany portret Adriena-Marie Legendre'a przedstawia w istocie polityka Louisa Legendre'a. „Sprawa Legendre'ów” doczekała się szczęśliwego finału. Matematyk nie tylko przestał nosić cudze oblicze, lecz dzięki internetowej dyskusji i szerokim poszukiwaniom odzyskał swą prawdziwą twarz, o której, jak się zdawało, nikt już nie pamiętał. Pisali o tym Peter Duren ${ }^{1}$ w 2010 r. oraz rok później Krzysztof Maślanka². W 2019 r. Józef Sawicki i Andrzej K. Wróblewski opisali sprawę przypisania oblicza lorda Kelvina polskiemu uczonemu Józefowi H. Osińskiemu. W 2011 r. Tamás Dénes ${ }^{4}$ przedstawił historię przypisania cudzej twarzy Jánosowi Bolyaiowi. Ten fałszywy wizerunek odkrywcy geometrii nieeuklidesowej można znaleźć nie tylko w artykułach i książkach, lecz również na znaczkach pocztowych. Bolyai urodził się w transylwańskim miasteczku Kluż-Napoka (węg. Kolozsvár). Upamiętniając swego rodaka w 1960 r. w setną rocznicę jego śmierci, znaczki pocztowe z jego (fałszywą) podobizną wydały Węgry i Rumunia (Ryc. 1).

Jedyny istniejący portret Bolyaia został zniszczony. Dénes twierdzi, że wiarygodnym wizerunkiem Janosa jest jego popiersie (Ryc. 2) znajdujące się przed Pałacem Kultury

1 P. Duren, Changing Faces: The Mistaken Portrait of Legendre, "Notices of the American Mathematical Society" t. 56, 2009, nr 11, s. 1440-1443.

2 K. Maślanka, Zamieniony portret i fikcyjna stała matematyczna. Adrien-Marie Legendre po latach, „Kwartalnik Historii Nauki i Techniki" t. 55, 2010, nr 2, s. 69-84.

3 J. Sawicki, A.K. Wróblewski, Jak Józef Herman Osiński został obdarzony obliczem lorda Kelvina. Proces poszlakowy, „Kwartalnik Historii Nauki i Techniki” t. 64, 2019, nr 2, s. 45-60.

4 T. Dénes, Real face of János Bolyai, „Notices of the American Mathematical Society” t. 58, 2011, nr 1, s. 41-51. 

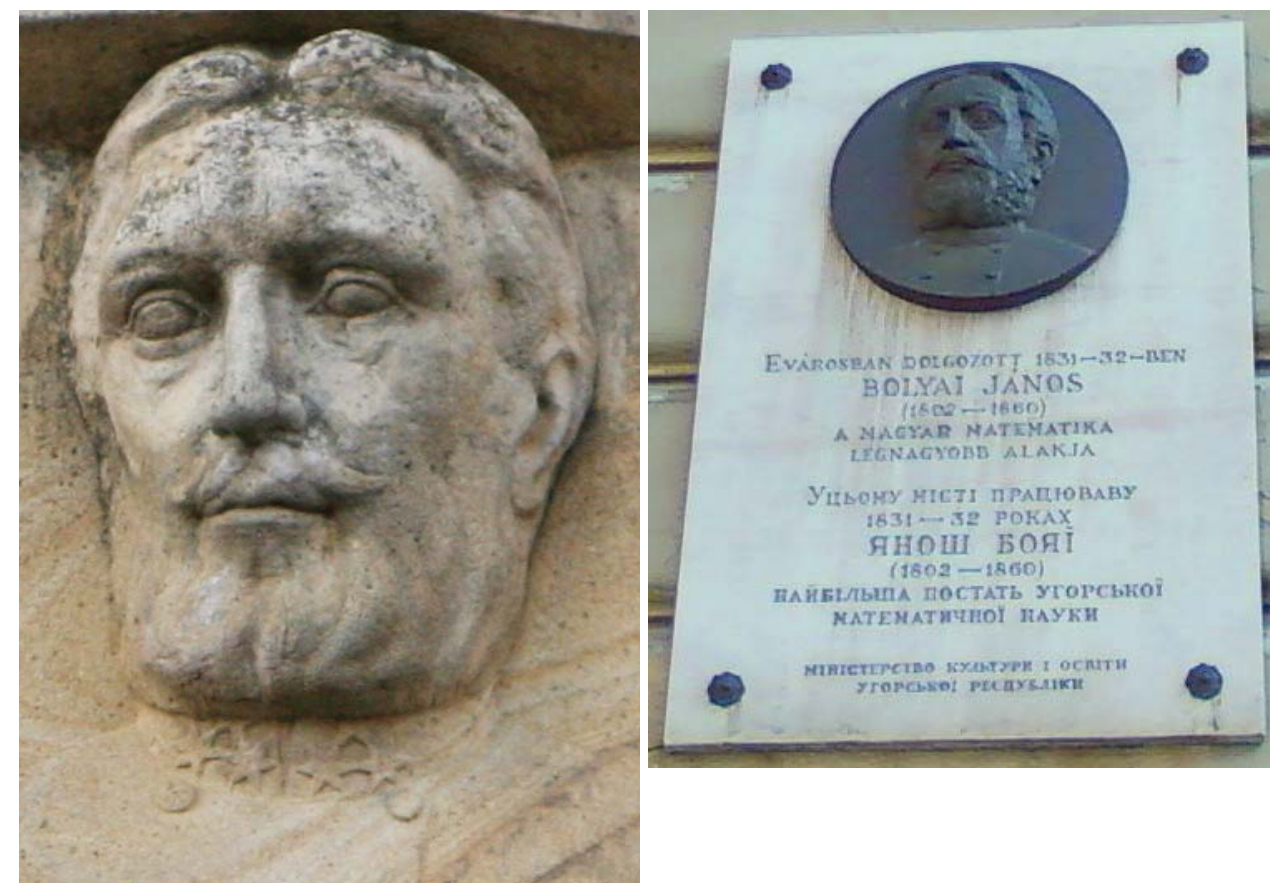

Ryc. 2. Od lewej: medalion z podobizną Jánosa Bolyaia, Marosvásárhely (domena publiczna); tablica upamiętniająca pobyt Bolyaia we Lwowie (domena publiczna).

w Târgu Mureș (węg. Marosvásárhely). Stworzono je w 1911 r., za życia Dénesa Boylaia, syna Jánosa, i innych osób, które pamiętały wizerunek odkrywcy geometrii nieeuklidesowej ${ }^{5}$. Na wzór tego popiersia wykonano płaskorzeźbę-medalion z podobizną uczonego (Ryc. 2), która znajduje się we Lwowie i upamiętnia pobyt Bolyaia w tym mieście w latach 1830-1831.

Wymienione pomyłki dotyczyły uczonych żyjących przed wynalezieniem lub upowszechnieniem fotografii. Z tamtych czasów zachowały się wizerunki tych osób, które miały fundusze lub osiągnięcia wystarczające do sporządzenia portretu, a przedstawiane osoby często podpisano. Wydaje się, że o pomyłkę trudno. W czasach późniejszych, po wynalezieniu fotografii, liczba osób, których oblicza zostały uwiecznione, wzrosła lawinowo, a z upływem lat do fotografii coraz rzadziej dołączano ich opisy. Obecnie żyjemy w „epoce obrazkowej”. Ambicją autorów tekstów i wydawców jest dołączenie portretu do każdej biografii, nawet do małego biogramu. Rezultaty można łatwo przewidzieć. Zamienione oblicza uczonych, których okres największej aktywności przypadł na początkowe dekady XX w., pojawiają się w naukowych publikacjach wydawanych przez prestiżowe wydawnictwa, trafiają do dzieł wybitnych historyków, a potem do tekstów upowszechniających naukę, stanowią także plagę Internetu.

Przykładem takiej sytuacji jest właśnie zdjęcie, które stało się inspiracją tego artykułu. Fotografia przedstawia grupę dwunastu młodych Polaków w atelier w Getyndze latem

5 To przekonanie nie ma wartości naukowej. W 1999 r. w Krakowie odsłonięto popiersie Stefana Banacha. Osoby pamiętające tego uczonego zgodnie stwierdzały rozbieżność z oryginalnym wyglądem matematyka; w szczególności niezadowolona była rodzina. 
1907 r. Ze zdjęciem tym pierwszy raz zetknęłam się na Konferencji z Historii Matematyki Polskiego Towarzystwa Matematycznego 24 maja 2007 r. w Iwoniczu-Zdroju. Ilustrowało ono odczyt Lecha Maligrandy Sto lat temu w Getyndze. Ogromną popularność zdjęcie uzyskało rok później, kiedy to zostało opublikowane w czasopiśmie „Wiadomości Matematyczne"6 jako jedna z ilustracji w artykule o Antonim Łomnickim ${ }^{7}$. W artykule pod zdjęciem znalazł się podpis:

Grupa polskich studentów i stypendystów. Getynga, lato 1907. Siedzą od lewej do prawej: Antoni Łomnicki (1881-1941), Werner, Antoni Przeborski (1871-1941), Tadeusz Banachiewicz (1882-1954), Wacław Sierpiński (1882-1969) i Kazimierz Józef Horowicz (1884-1920). Stoją od lewej do prawej: Szulc, Jan Norbert Króo (18861942) - fizyk, Stanisław Kępiński (1867-1908), Władysław Dziewulski (1878-1962) - astronom i astrofizyk, Włodzimierz Stożek (1883-1941) i Hugo Dionizy Steinhaus (1887-1972).

Prowadząc badania w ramach projektu Studia i badania naukowe polskich matematyków, fizyków i astronomów na Uniwersytecie w Getyndze (1895-1933), podjęłam się trudnego zadania wiarygodnej identyfikacji postaci widocznych na zdjęciu CBM IMPAN sygn. ZF.263. Badania te rozpoczęłam, gdyż chciałam wykorzystać zdjęcie jako dodatek do krótkiej informacji o wystawie Obrazy z historii Polskiej nauki. Matematycy, fizycy i astronomowie na Uniwersytecie w Getyndze (1895-1933). Wystawa zaplanowana była na wrzesień 2019 r. i miała być jedną z kilku oficjalnych wystaw towarzyszących „Jubileuszowemu Zjazdowi Matematyków Polskich w stulecie PTM". Już na samym początku przygotowań, jesienią 2018 r., mój niepokój wzbudził zbyt młody wygląd domniemanego Stanisława Kępińskiego i właśnie wtedy rozpoczęłam gruntowne badania. Głównym materiałem służącym do weryfikacji stawianych w trakcie badań hipotez były materiały z archiwum uniwersytetu w Getyndze (Universitätsarchiv Göttingen w Niedersächsische Staats- und Universitätsbibliothek Göttingen) ze szczególnym uwzględnieniem ksiąg immatrykulacyjnych (Matricula in studiosorum Academia Georgicae Augusta ${ }^{8}$, dalej Matricula) oraz z Archiwum Uniwersytetu Jagiellońskiego. Pomocne były również spuścizny (Tadeusz Banachiewicz, Wacław Dziewulski, Władysław Dziewulski, Felicjan Kępiński, Hugo Steinhaus), w tym wspomnienia i dzienniki, których manuskrypty lub maszynopisy zgromadzone zostały w Archiwum PAN w Warszawie. Posiłkowałam się także biogramami uczonych opublikowanymi w Polskim Słowniku Biograficznym i innych opracowaniach.

Korzystając z kopii ksiąg immatrykulacyjnych oraz publikowanych spisów studentów (Amtliches Verzeichnis des Personals und der Studierenden der Königl. Georg-AugustUniversität zu Göttingen ${ }^{9}$, dalej Amtliches) uniwersytetu w Getyndze, sporządziłam listę

„Wiadomości Matematyczne" to czasopismo założone przez Samuela Dicksteina w 1897 r. Od momentu założenia do jego śmierci w 1939 r. wydawane było z jego prywatnej subwencji. Po II wojnie światowej, w 1955 r., Polskie Towarzystwo Matematyczne wznowiło wydawanie czasopisma i od tego czasu wychodzi ono jako druga seria Roczników PTM.

7 L. Maligranda, Antoni Łomnicki (1881-1941), „Wiadomości Matematyczne” t. 44, 2001, nr 2, s. 65.

8 Universitätsarchiv Göttingen [UniA Gö], Matricula in studiosorum Academia Georgicae Augusta, lata 18851933.

9 UniA Gö, Amtliches Verzeichnis des Personals und der Studierenden der Königl. Georg-August-Universität zu Göttingen, Aus das halbe Jahr von Ostern bis Michaelis 1907. 
Polaków, którzy latem 1907 r. studiowali na Uniwersytecie Georga-Augusta. Zawiera ona nazwiska 18 mężczyzn. W kolejności alfabetycznej nazwisk podaję: imię, nazwisko, miejsce zamieszkania (uzupełnione dokładnym adresem, o ile taki podano) oraz miejsce urodzenia. Wszystkie poniższe dane pochodzą z Matriculi z lat 1905-1907, a znajdujące się tam wpisy były dokonywane osobiście przez zainteresowanych. Lista ta stanowiła główną podstawę dalszych badań.

Lista polskich studentów matematyki immatrykulowanych w semestrze letnim $1907 \mathrm{r}$. na Uniwersytecie Georga-Augusta w Getyndze

Tadeusz Banachiewicz, Warszawa, Żórawia 38, ur. w Warszawie, Wacław Dziewulski, Warszawa, Podwale 4, ur. w Warszawie, Ludwik Jagustyn, Kraków, Mikołajska 5, ur. w Przegini Narodowej, Kazimierz Horowicz, Łódź, ur. w Warszawie, Eugen [Eugeniusz] Kahl, Warszawa, ul. Hoża 68 m. 15, ur. w Kielcach, Felicjan Kempinski [Kępiński], Piotrków, ur. w Piotrkowie,

Nikolauss [Mikołaj] Kowalewskij [Kowalewski], Kamieniec Podolski, ur. w Kamieńcu Podolskim,

Johann Kroó [Jan Kroo], Kraków, Gertrudy 2, ur. w Krakowie, Antoni Łomnicki, Lwów, Jabłonowskich 2, ur. we Lwowie, Julian Przedborski, Łódź, ur. w Łodzi, Leo Schultz, Warszawa, Elektoralna 27, ur. w Warszawie, Bronisław Schupp, Warszawa, Nowowielka 7, ur. w Kole, Wacław Sierpiński, Warszawa, Marszałkowska 73, ur. w Warszawie, Hugo D. Steinhaus, Jasło, ur. w Jaśle, Włodzimierz Stożek, Kraków, Graniczna 16, ur. w Mostach Wielkich, Adam Szadurski, Grodno, ur. w Grodnie, Wenceslaus [Wacław] Werener, Warszawa, Chłodna 5, ur. w Warszawie, Stanisław Landau [Ziemecki] ${ }^{10}$, Warszawa, ur. w Warszawie ${ }^{11}$.

Dotarłam do kopii oryginalnego zdjęcia (Ryc. 4). I tu czekała mnie pierwsza niespodzianka. Na zdjęciu ktoś (była to jedna osoba, a nie kilka, o czym świadczy jednolity charakter pisma) dopisał nazwiska; w domyśle są to nazwiska sfotografowanych mężczyzn (Ryc. 3). Starałam się ustalić dane na temat samego zdjęcia (autora, konkretne miejsce, dokładną datę) oraz informacje o autorze identyfikacji. Archiwum Matematyków Polskich było zbiorem bezcennych pamiątek przekazywanych do Sopotu z potrzeby serca, nie zawsze przechowywanych z zachowaniem wszelkich archiwalnym procedur ${ }^{12}$. Dziś trudno dotrzeć do poszukiwanych przeze mnie informacji. Niestety nie wiadomo, kto

10 Stanisław Ziemecki zmienił nazwisko Landau na Ziemecki po 1907 r., jeszcze w latach trzydziestych XX w. podpisywał swe prace Landau-Ziemecki.

11 UniA Gö, Matricula studiosorum in Academia Georgicae Augusta, Vol. XXI, SS 1906/1907 oraz tomy z lat poprzedzających.

12 Z. Pawlikowska-Brożek, M. Sękowska, D. Węglowska, Archiwum Matematyczne w Sopocie, „Kwartalnik Historii Nauki i Techniki" t. 38, 1993, nr 1, s. 121-136. 


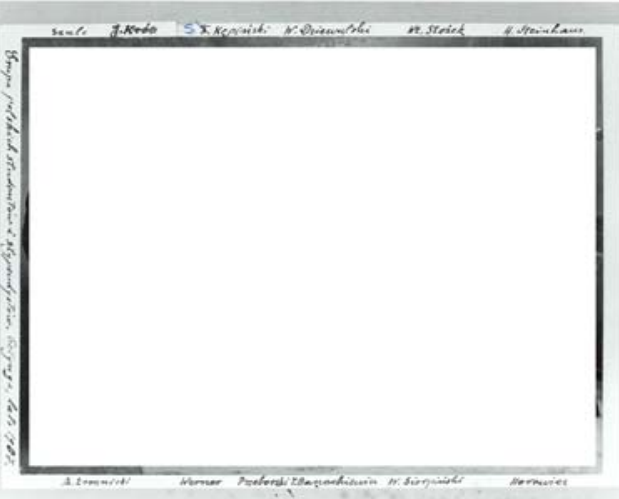

Ryc. 3. Kopia podpisów na zdjęciu CBM IMPAN, sygn. ZF.263. dokonał pierwszej identyfikacji sfotografowanych osób. Nazwiska zostały zapisane czarnym kolorem (długopisem) na białych marginesach zdjęcia. Na lewym marginesie znajduje się informacja ogólna (tytuł): „Grupa polskich studentów i stypendystów. Getynga, lato 1907". Na górnym marginesie zapisano: „Szulc, J. Króo, F. Kępiński, W. Dziewulski, Wł. Stożek, H. Steinhaus". Można logicznie przypuszczać, że w ten sposób opisane są osoby stojące. Na dolnym marginesie zapisano: „A. Łomnicki, Werner, Przeborski, T. Banachiewicz, W. Sierpiński, Horowicz". To opis postaci siedzących. Osoba dokonująca opisu nie znała imion Szulca, Wernera i Horowicza (lub ich zapomniała). Na zdjęciu są jeszcze dwie utrudniające identyfikację zmiany. Jedna z nich to rozmazanie dwóch ostatnich liter w nazwisku Kroo, druga to skreślenie inicjału przy nazwisku Kępińskiego i dopisanie tam litery "S”. Dopisek został wykonany niebieskim kolorem przez inną osobę niż ta, która robiła pierwotny opis.

Pierwsza weryfikacja przeprowadzonych wcześniej identyfikacji to porównanie zestawionej listy z opisem zdjęcia. A. Łomnicki, siedzący jako pierwszy z lewej strony, to z pewnością Antoni Łomnicki (1881-1941). Identyfikacja była prosta. Znane są zdjęcia Łomnickiego z podobnego okresu, wiele z nich opublikował w swym artykule Lech Maligranda ${ }^{13}$. Potwierdzeniem tej identyfikacji jest również osobisty wpis Antoniego Łomnickiego do księgi immatrykulacyjnej w 1907 r. Kolejna postać nie budząca wątpliwości to siedzący obok niego fizyk Wacław Werner (1879-1948), który, tak jak Łomnicki, jest na liście studentów i którego zdjęcia są znane. Sprawa skomplikowała się przy sąsiedzie Wernera, domniemanym Przeborskim. Antoni Przeborski, matematyk i mechanik, urodził się w 1871 r. i powinien być znacznie starszy od wszystkich zgromadzonych, jako że był dziesięć lat starszy od Łomnickiego. Tymczasem na zdjęciu widzimy uderzająco przystojnego młodzieńca. Przeborski był raczej niski, nosił okulary ${ }^{14}$ i z pewnością nie był aż tak młody. Na sporządzonej liście studentów getyńskiej uczelni widnieje Julian Przedborski i to zapewne on, a nie Antoni Przeborski, znalazł się w grupie sfotografowanych mężczyzn. Dowody na potwierdzenie tej hipotezy podane zostaną w dalszej części artykułu. Kolejna postać, człowiek, który opiera się na poręczy fotela, to z pewnością astronom Tadeusz Banachiewicz (1882-1954). Spuścizny Banachiewicza znajdują się w Archiwum UJ ${ }^{15}$ oraz w Bibliotece Głównej Uniwersytetu Pedagogicznego w Krakowie $^{16}$, zdjęcia są liczne, materiał porównawczy był wystarczający, by w tym szczupłym młodzieńcu rozpoznać późniejszego dojrzałego, potężnie zbudowanego mężczyznę. Banachiewicz oparł się na ramieniu swego przyjaciela, matematyka Wacława Sierpińskie- 


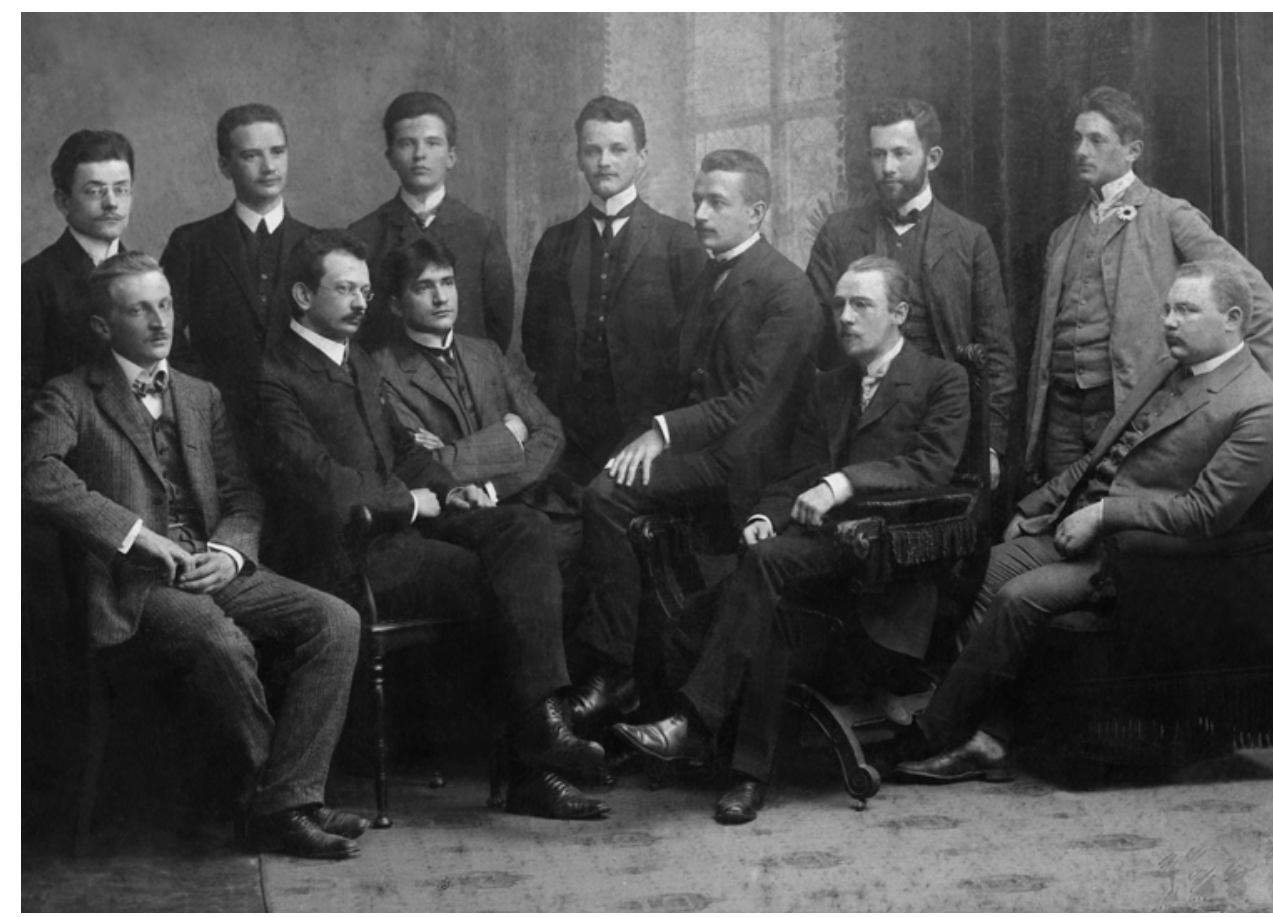

Ryc. 4. Grupa polskich studentów i stypendystów. Getynga, lato 1907 roku, autor nieustalony (CBM IMPAN, sygn. ZF.263).

Siedzą od lewej: Antoni Łomnicki, Wacław Werner, Julian Przedborski, Tadeusz Banachiewicz, Wacław Sierpiński i Kazimierz Józef Horowicz.

Stoją od lewej: Leo Schultz (Leon Szulc?), Jan Norbert Kroo, Felicjan Kępiński, Wacław Dziewulski, Włodzimierz Stożek i Hugo Dionizy Steinhaus

go (1882-1969). W tym przypadku rozpoznanie również nie budzi wątpliwości, chociaż osoby przyzwyczajone do zdjęć Sierpińskiego z czasów po II wojnie światowej mogą być zaskoczone. Ostatni spośród siedzących to statystyk Kazimierz Horowicz (1884-1920). Nazwisko Horowicza jest na sporządzonej liście, do kilku jego zdjęć można łatwo dotrzeć. Tu osoba dokonująca identyfikacji również się nie pomyliła. Przejdźmy do rzędu osób stojących. Pierwszy od lewej strony to domniemany Szulc. Jakie nosi imię? Maligranda opisał go jako Stefana Szulca, statystyka ${ }^{17}$. Rozwiązanie jest jednak inne. Niestety to znalezione przeze mnie - Leo Schultz (Leon Szulc) - stanie się początkiem nowej zagadki; o identyfikacji tej będzie mowa w kolejnej części artykułu. Drugi mężczyzna od lewej strony to fizyk matematyczny Jan Kroo ${ }^{18}$ (1886-1941 lub 1942). Tu nie było kłopotów z potwierdzeniem identyfikacji, kłopoty stanowiło same nazwisko - ta kwestia zostanie poruszona w dalszej części pracy. Jego sąsiad to Kępiński. Czy na pewno Stanisław (1867-1908)? Stanisław byłby najstarszym mężczyzną sportretowanym na tym zdjęciu. To zapewne Felicjan Kępiński, którego nazwisko jest na liście studentów; szczegóły tej identyfikacji również zostaną

17 Informacja przekazana autorce, 2 III $2018 \mathrm{r}$.

18 Jego nazwisko pisane jest Kroo bez akcentu oraz Kroó z akcentem na ostatnią samogłoskę. Odręczne podpisy Kroo z dokumentów w Universitätsarchiv Göttingen nie mają akcentu. 
przedstawione w dalszej części pracy. Kolejna osoba to W. Dziewulski. Maligranda napisał, że jest to Władysław Dziewulski ${ }^{19}$. Postanowiłam sprawdzić tę tezę, posiłkując się materiałem archiwalnym. Udało mi się przekonująco zweryfikować, który z braci Dziewulskich został tu sportretowany. O tym też będzie mowa w dalszej części artykułu. Dwaj ostatni bohaterowie (w kolejności od lewej strony) to poprawnie zidentyfikowani matematycy Włodzimierz Stożek (1883-1941) oraz Hugo Dionizy Steinhaus (1887-1972).

Podsumujmy przeprowadzoną weryfikację. Niepoprawna identyfikacja została dokonana dwa razy - Szulc, Kępiński; wątpliwa również dwa razy - Przeborski i Władysław Dziewulski; nieprawidłowe nazwisko pojawiło się raz - Króo. Bezdyskusyjnie poprawnie zidentyfikowanych jest 7 osób, czyli 58\%. W kolejnych częściach artykułu opiszę poszukiwania, które prowadziłam, aby dokonać prawidłowej identyfikacji bohaterów zdjęcia ZF.263.

\section{Julian Przedborski}

Domniemany bohater zdjęcia ZF.263, Antoni Przeborski²0 urodził się 25 maja 1871 r. na Ukrainie. Matematykę studiował na Cesarskim Uniwersytecie w Kijowie, gdzie rozpoczął starania o magisterium, które ostatecznie uzyskał w Moskwie w 1902 r. Przeborski w Getyndze przebywał w 1904 r. Na studia zagraniczne otrzymał rosyjskie stypendium rządowe. Informacje, jakimi dysponujemy na potwierdzenie tych faktów, to jego wpis do księgi immatrykulacyjnej oraz drukowane sprawozdanie z jego pobytu w Getyndze21. W Matriculi znajduje się wpis „Pscheborsky Anton, Charkow, Russland"22. Przy wpisie brakuje daty opuszczenia uniwersytetu. Taka sytuacja nie jest rzadka; zwykle ta data pojawia się przy tych osobach, które odbyły pełne studia i starały się o poświadczenie ukończonych studiów. Przeborski przebywał w Getyndze krótko - nic dziwnego, że nie odebrał odpłatnego poświadczenia ukończonych kursów. W semestrze zimowym roku akademickiego 1904/1905 już brak jego wpisu. Potwierdzenie, że opuścił Getyngę wraz z końcem roku akademickiego 1903/1904, znajdujemy w jego sprawozdaniu, gdzie jako datę przyjazdu podaje 20 kwietnia, a jako datę wyjazdu z Niemiec - 20 sierpnia 1904 roku $^{23}$. Od powrotu z Niemiec pozostawał w Charkowie, gdzie w 1908 r. obronił doktorat i został profesorem tamtejszego uniwersytetu. Przeborski w 1907 r. nie przebywał w Getyndze.

Kim jest więc przystojny młodzieniec ze zdjęcia z 1907 r.? Pierwszą podpowiedź dała lista studentów, którzy w letnim semestrze 1907 r. byli zapisani na uniwersytet. Znalazł się wśród nich Julian Przedborski. Informację tę należy jednak potwierdzić

19 L. Maligranda, Antoni Łomnicki, s. 65.

20 Z.S. Olesiak, Profesor Antoni Przeborski (1871-1941), „Kwartalnik Historii Nauki i Techniki” 2001, t. 46, nr 3, s. 125-132 oraz K. Tatarkiewicz, Matematyk, a nie Mechanik (Antoni Przeborski), [w:] Matematycy polskiego pochodzenia na obczyźnie. Materiały z XI Ogólnopolskiej Szkoły Historii Matematyki, Kołobrzeg, 5-9 maja 1997 , red. S. Fudali, Szczecin 1998, s. 143-160.

21 A.P. Pšeborskij [Przeborski], Otčet o zagraničnoj komandirovk” privat'-docenta A.P. Pšeborskago, „Zapiski Imperatorskago Har'kovskogo Universiteta" t. 1, 1906, s. 26-34.

22 UniA Gö, Matricula studiosorum in Academia Georgicae Augusta, Vol. XVII, SS 1903/04, poz. 663. Data wpisu 10 maja $1904 \mathrm{r}$.

23 A.P. Pšeborskij [Przeborski], Otčet o zagraničnoj. 
w innych źródłach. Tu wykorzystałam wspomnienia Felicjana Kępińskiego, Romana Ingardena (1893-1970) i Steinhausa. Jako pierwsze przywołajmy wspomnienia Kępińskiego odczytane w Toruniu w czasie sesji poświęconej pamięci Władysława Dziewulskiego:

Jest już tu [w Getyndze] od 1906 jego brat Wacław i licząca około 40 osób kolonia polska studentów różnych specjalności. Z pamięci przytoczę nazwiska: Banachiewicz, Dmochowski, Dziewulscy, Fryling, Gawlik, Horowicz, Janoszek, Jantzen, Kahl, Kępiński, Kroo, Łomniccy, Moroński, Przedborski, Rotowie, Sierpiński, Steinhaus, Stożek, Schupp, Werner, z których to nazwisk wiele ma dziś dzień dobre brzmienie lub jest otaczane najlepszą pamięcią ${ }^{24}$.

Jednak Przedborski, nie Przeborski. Tę informację potwierdzają wspomnienia Ingardena. Pisze on, że w Getyndze byli fizycy Moroński i Przedborski25. Trzecim źródłem w tym śledztwie jest maszynopis wspomnień Steinhausa zdeponowany w Archiwum PAN w Warszawie. Czytamy w nim:

Nie byli to jedyni Polacy w Getyndze; studiowali tam bracia Dziewulscy: Władysław był asystentem astronomii, młodszy, Wacław studentem fizyki; astronomię studiował Felicjan Kępiński z Piotrkowa, później pojawił się L. Chwistek z Krakowa (z siostrą), astronom Tadeusz Banachiewicz, Włodzimierz Stożek, J. Przeborski [...] $]^{26}$.

Przy nazwisku „Przeborski” w oryginalnym maszynopisie znajduje się inicjał inny niż „A."! Wątpliwe jest, aby Steinhaus pomylił imię, raczej maszynistka zgubiła jedną literę w nazwisku. Inicjał jest zgodny z imieniem Przedborskiego i tym samym wspomnienia Steinhausa również zdają się potwierdzać tezę, że na zdjęciu znalazł się Julian Przedborski, nie Antoni Przeborski27. Inicjał „J." przy nazwisku „Przeborski” pojawił się również we Wspomnieniach Steinhausa opublikowanych przez krakowski "Znak"28.

Przedborski urodzony i zamieszkały $w$ Łodzi zapisał się na studia na Wydziale Filozoficznym Uniwersytetu Georga-Augusta w Getyndze 22 kwietnia 1905 r. i pozostał tam co najmniej do lata 1907 r. $^{29}$ Julian Przedborski (1886-1931) to prawdopodobnie syn żydowskiego lekarza Ludwika Przedborskiego (1857-1911) z Łodzi. Poza datami życia wiemy o Julianie Przedborskim niewiele. Szersze informacje przedstawione zostaną w przygotowywanej monografii ${ }^{30}$.

24 F. Kępiński, Pierwsze lata pracy naukowej Władysława Dziewulskiego [przemówienie odczytane na uroczystym posiedzeniu poświęconym pamięci profersora Władysława Dziewulskiego $14 \mathrm{~V} 1962$ r.], maszynopis, Instytut Astronomii UMK, cytowane za: Władysław Dziewulski 1878-1962, red. C. Iwaniszewska, Warszawa - Poznań - Toruń 1978, s. 22.

25 R. Ingarden, Wspomnienia z Getyngi, „Czasopismo Artystyczno-Literackie” t. 6, 1998, nr 5-6.

26 Archiwum PAN w Warszawie [APAN], III-204, Materiały Hugona D. Steinhausa, Wspomnienia, fragment do $1920 \mathrm{r}$.

27 Wspomnienia Steinhausa opublikowane zostały w 1970 r. przez czasopismo „Znak”. To i kolejne książkowe wydania Wspomnień i zapisków Steinhausa, poczynając od wydanych przez Aneks w Londynie, zawierają korekty pierwszego redaktora tekstu. Korekta ta została naniesiona długopisem na maszynopis znajdujący się w spuściźnie. W przywołanym przypadku korektor skreślił inicjał „J." i pozostawił nazwisko Przeborski. Niestety w ten sposób zamiast prawidłowej weryfikacji informacji do tekstu wprowadzono trudny do późniejszego naprawienia błąd.

28 H. Steinhaus, Wspomnienia, „Znak” 1970, nr 1, s. 86.

29 UniA Gö, Matricula studiosorum in Academia Georgicae Augusta, 1905, Ostern, poz. 68.

30 D. Ciesielska, L. Maligranda, J. Zwierzyńska, W świątyni nauki, mekce matematyków... Studia i badania naukowe polskich matematyków, fizyków i astronomów na Uniwersytecie w Getyndze (1889-1933), w przygotowaniu. 

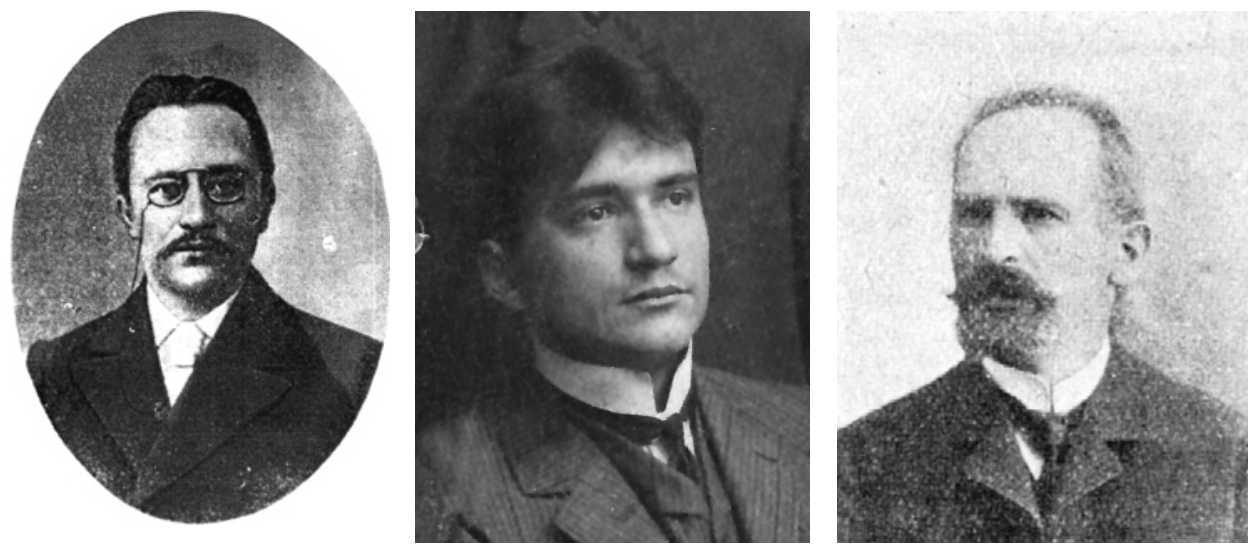

Ryc. 5. Od lewej: kopia zdjęcia Antoniego Przeborskiego (Zbigniew S. Olesiak, Profesor Antoni Przeborski (1871-1941), "Kwartalnik Historii Nauki i Techniki” t. 46, 2001, nr 3, s. 127);

Julian Przedborski, fragment zdjęcia CBM IMPAN, sygn. ZF.263;

Ludwik Przedborski (domena publiczna, pl.wikipedia.org/wiki/Ludwik_Przedborski).

Maligranda, polegając na podpisie na marginesie zdjęcia, w swej pracy z $2008 \mathrm{r}$. identyfikuje tę postać jako Antoniego Przeborskiego ${ }^{31}$; w artykule o pobycie Orlicza w Getyndze z 2018 r. dokonuje już poprawnej identyfikacji ${ }^{32}$. Błąd zawiera również przypis redakcyjny w książce o Władysławie Dziewulskim ${ }^{33}$, w którym redaktor tomu uzupełniła niektóre wymienione przez Felicjana Kępińskiego ${ }^{34}$ nazwiska imionami i tak oto zamiast Juliana Przedborskiego wspomniała Antoniego Przeborskiego.

\section{Leo Schultz}

Rozpoznanie Szulca jako Stefana obudziło mój niepokój dość wcześnie, jeszcze przed pracami nad wystawą plakatów. Maligranda w 2018 r. podał, że na zdjęciu znajduje się Stefan Szulc ${ }^{35}$, ja znalazłam innego słynnego uczonego, Gustawa Szulca (1884-1941). Gustaw był lekarzem, zatem zapewne nie o niego chodzi. Trzeba było się jednak upewnić, jako że w Getyndze matematykę studiowali w tym czasie mistrz szachowy i psycholog, mógł więc studiować ją również przyszły lekarz. To jednak nie on. W żadnym biogramie nie ma informacji o jego pobycie w Getyndze. Może to rację miał Maligranda i jest to Stefan Szulc (1881-1956)? Statystycy studiujący matematykę to sytuacja typowa. Jednak podobnie jak w przypadku Gustawa, w żadnym biogramie Stefana nie ma informacji o jego pobycie w Getyndze. Dzięki kwerendzie w Getyndze w 2018 r. dowiedziałam się, że jedyny Szulc (Schultz) z ziem polskich studiujący 
w 1907 r. na Uniwersytecie Georga-Augusta matematykę to według Matriculi ${ }^{36}$ i Amtliches $^{37}$ Leo (Leon) z Warszawy.

Niestety to rozwiązanie stało się początkiem nowej zagadki. O Leonie Szulcu vel Leo Schultzu nie wiemy prawie nic. Znany jest jego warszawski adres (ul. Elektoralna 27) oraz miejsce urodzenia (Warszawa). Leon Szulc z Warszawy, którego dane mniej więcej pasują do znalezionego w Getyndze Leona, to pianista i kompozytor. O nim też niewiele wiadomo, nie wiadomo nawet, czy mieszkał przy ul. Elektoralnej. Tej zagadki, przynajmniej do dziś, nie udało się rozwiązać.

\section{Felicjan Kępiński}

Identyfikacja tej postaci, jak wspominałam, wzbudziła mój niepokój jesienią 2018 r. Czy na pewno jest to Stanisław Kępiński? Stanisław byłby najstarszym mężczyzną sportretowanym na tym zdjęciu, w momencie zrobienia fotografii miałby 40 lat. Czy ten młodzieniec na zdjęciu może mieć 40 lat? Z pewnością nie.

Udało się dotrzeć do informacji w Archiwum UJ na temat pobytu Stanisława Kępińskiego w Getyndze. Kępiński znalazł się w mekce matematyków dzięki stypendium Fundacji Klimowskiego. Radca kolegialny Klimowski, zmarły w 1885 r. w Odessie, zapisał na stypendia dla absolwentów wyższych uczelni, głównie UJ, 37400 rubli w celu umożliwienia im zagranicznych studiów w najlepszych ośrodkach naukowych i wykształcenia docentów najbardziej potrzebnych dla polskich uniwersytetów w Krakowie i Lwowie ${ }^{38}$. Absolwent UJ Stanisław Kępiński otrzymał takie stypendium w 1890 r $^{39}$. Stypendium było ponawiane na kolejne cztery lata. Kępiński w 1891 r. uzyskał doktorat filozofii UJ i dzięki otrzymanym funduszom wyjechał na studia matematyczne na Uniwersytecie Georga-Augusta w Getyndze. Z pobytu naukowego pisał bardzo obszerne sprawozdania ${ }^{40}$. Dowiadujemy się z nich, że wysłuchał tam wykładów Felixa Kleina (1949-1925) z teorii powierzchni Riemanna oraz z teorii równań różniczkowych, wykładu Hermanna Schwarza (1843-1921) o powierzchniach minimalnych i Heinricha Webera (1842-1913) z algebry, w tym z teorii Galois. Dokumenty z archiwum w Getyndze uzupełniły tę listę o rachunek różniczkowy, algebrę i wyższą geometrię u Kleina ${ }^{41}$. Stanisław Kępiński opuścił Getyngę w 1893 r. Warto jednak podkreślić jedno ważne osiągnięcie Kępińskiego związane z jego pobytem w Getyndze. To on jako pierwszy Polak opublikował artykuł w renomowanym getyńskim czasopiśmie ${ }^{42}$

36 UniA Gö, Matricula studiosorum in Academia Georgicae Augusta, 1906, Michealis, poz. 338.

37 UniA Gö, Amtliches Verzeichnis des Personals und der Studierenden der Königl. Georg-August-Universität zu Göttingen, Aus das halbe Jahr von Ostern bis Michaelis 1907, s. 73.

38 J. Dybiec, Finansowanie nauki i oświaty w Galicji 1860-1918, Kraków 1979. Więcej o pobycie stypendialnym Kępińskiego w Getyndze w artykule: D. Ciesielska, Stypendyści Akademii Umiejętności i Uniwersytetu Jagiellońskiego na Uniwersytecie Georga-Augusta w Getyndze w latach 1891-1914. Matematyka, „Studia Historiae Scientiarum" t. 19, 2020, s. 375-422.

39 AUJ, WF II 103, Fundacja Kazimierza Klimkowskiego 1889-1939.

40 Ibid.

41 Niedersächsische Staats- und Universitätsbibliothek Göttingen [SUB Göttingen], Nachlass Felix Klein, Cod. Ms. F. Klein 7E., Hörerverzeichnisseder Vorlesungen F. Kleins 1871-1920, rok akademicki 1891/1892.

42 S. Kempinsei [Kępiński], Ueber Fuchs'sche Functionen zweier Variabeln, „Mathematische Annalen” 1896, t. 47, nr 4, s. 573-588. 

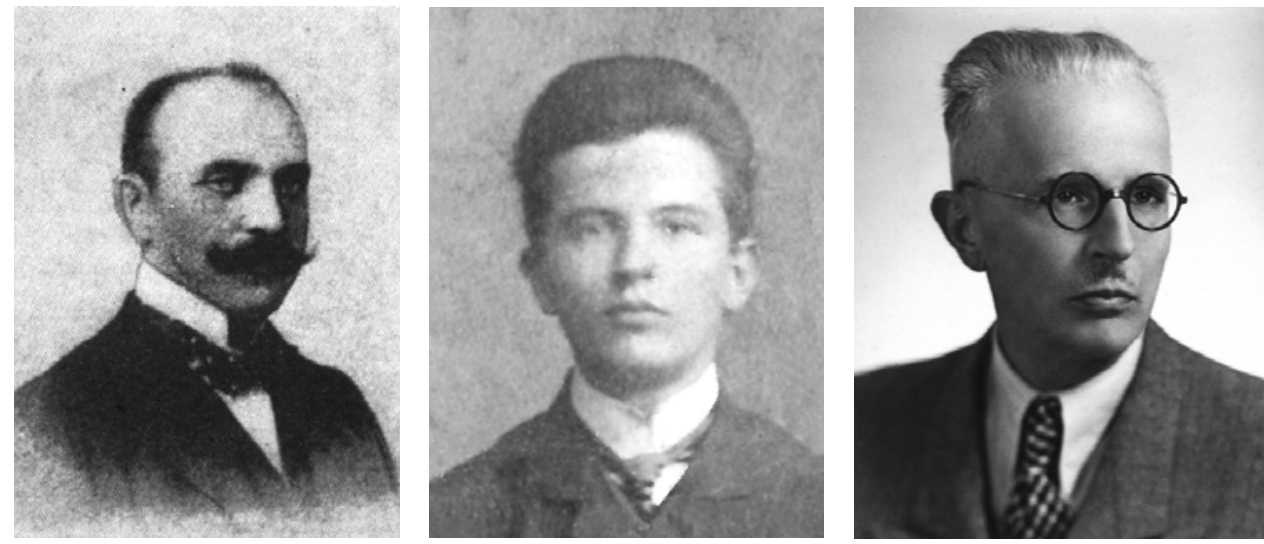

Ryc. 6. Od lewej: Stanisław Kępiński (domena publiczna); Felicjan Kępiński, fragment zdjęcia CBM IMPAN, sygn. ZF 263; Felicjan Kępiński, Archiwum PTA, ze zbiorów Andrzeja Kępińskiego.

"Mathematische Annalen”. Jednak to nie on studiował w Getyndze w 1907 r. i nie jego postać widnieje na zdjęciu ZF.263.

W trakcie kwerendy upewniłam się, że jedyny Kępiński (Kempinski), który w 1907 r. studiował matematykę na Uniwersytecie Georga-Augusta to młody astronom Felicjan ${ }^{43}$. Poza dokumentami z archiwum znalazły się inne potwierdzenia tej tezy. Felicjan pojawia się we wspomnieniach Steinhausa; przypomnijmy: „Nie byli to jedyni Polacy w Getyndze [...] astronomię studiował Felicjan Kępiński z Piotrkowa"44 i dodajmy:

Za drugi przedmiot uboczny wybrałem astronomię i wraz z F. Kępińskim chodziłem na ćwiczenia do Obserwatorium, gdzie pod kierunkiem prof. Ambronna rachowaliśmy obserwacje poczynione w Afryce przy rozgraniczeniu Konga pomiędzy Belgów i Niemców ${ }^{45}$.

Sam Felicjan napisał wspomnienia z Getyngi ${ }^{46}$, które również potwierdzają, że istotnie był tam w $1907 \mathrm{r}$.

Skąd taki błąd w identyfikacji? Pierwszym, który wprowadził tę zmianę, był „korektor" zdjęcia. To on skreślił inicjał „F.” i dopisał „S.”. Zapewne był matematykiem lub osobą, która interesowała się historią matematyki. Stanisław Kępiński to znany matematyk działający na przełomie XIX i XX w. Powszechnie wiadomo, że studiował matematykę w Getyndze. Błąd pojawił się i został rozpowszechniony dosyć wcześnie. Zdjęcie to stanowi ilustrację biogramu Stanisława Kępińskigo ${ }^{47}$ w wydanym w 2003 roku Słowniku biograficznym matematyków polskich. Umieścił je w swej monografii Matematycy XIX i XX wieku związani z Polską Roman Duda ${ }^{48}$. W 2008 r. w artykule

47 Słownik biograficzny matematyków polskich, red. S. Domoradzki, Z. Pawlikowska-Brożek, D. Węglowska, Tarnobrzeg 2003, s. 100.

48 R. Duda, Matematycy XIX i XX wieku związani z Polską, Wrocław 2012, s. 209. 
o Łomnickim ten sam błąd popełnił Maligranda, jednak w artykule z 2018 r. o pobycie Orlicza w Getyndze postać identyfikuje już poprawnie ${ }^{49}$.

\section{Wacław Dziewulski}

Tu potrzeba wiarygodnej identyfikacji pojawiła się najpóźniej. Trochę to dziwi, bo o pomyłkę w tym przypadku nietrudno. Bracia Dziewulscy wiekiem różnili się niewiele, co więcej, byli bardzo podobni. Tam, gdzie o pomyłkę było najłatwiej, nikt nie podawał $w$ wątpliwość identyfikacji dokonanej w 2008 r. ${ }^{50}$ Nie wzbudziły niepokoju zdjęcia Władysława Dziewulskiego sprzed Obserwatorium w Getyndze (Ryc. 7 i 8) ${ }^{51}$, na których nosi on charakterystyczne wąsy, których postać na zdjęciu ZF.263 nie ma.

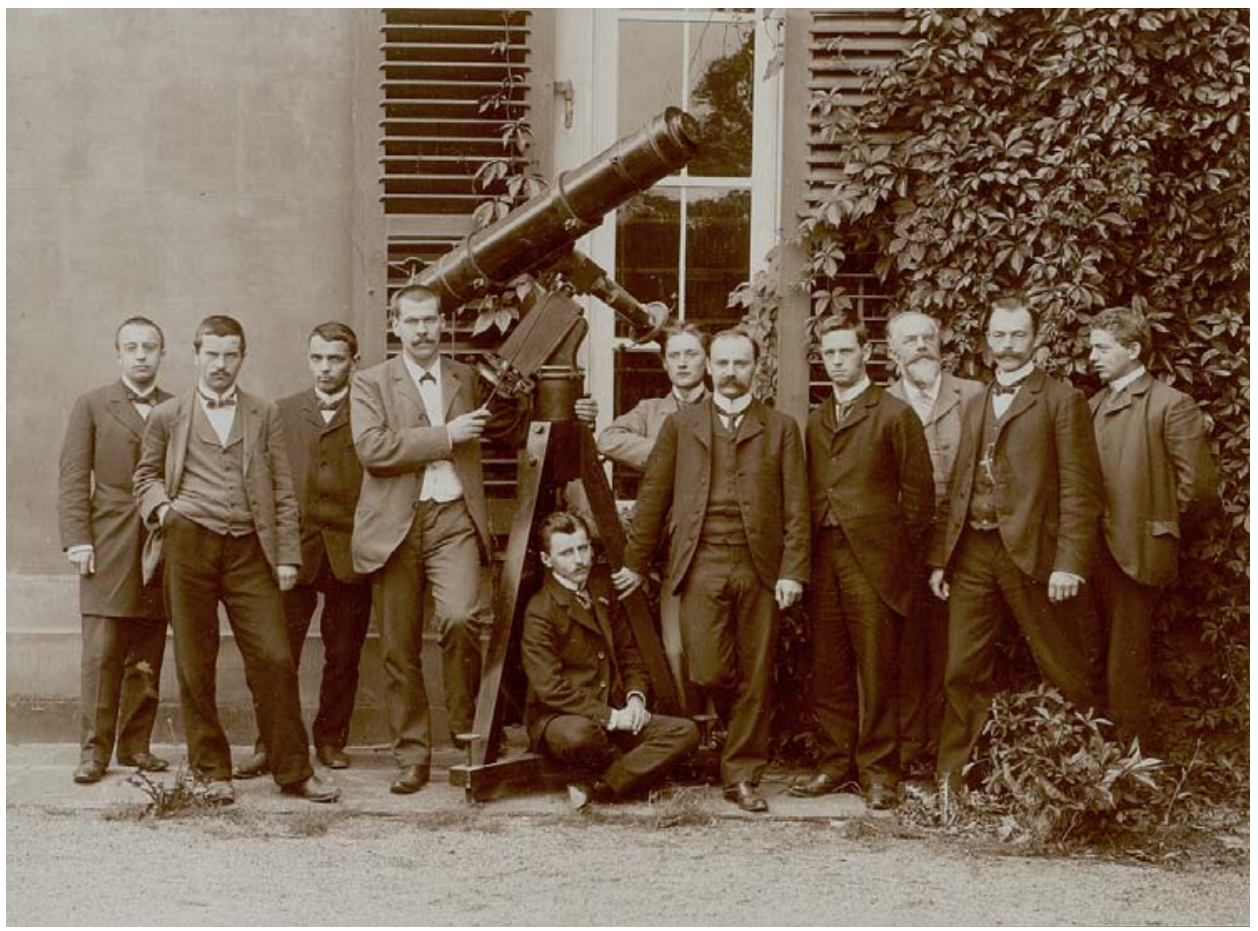

Ryc. 7. Od lewej: Otto Birck, Hugo Kistler, Heinrich Blasius, Johannes M. Knapp, Władysław Dziewulski (siedzący), Albert von Brunn, Karl Schwarzchild, Burt Leroy Newkirk, Leopold Ambronn, Bruno Meyermann, Martin Linnemann. Getynga, przed Obserwatorium Astronomicznym, lipiec 1903 roku, (SUB Göttingen, Nachlass Karl Schwarzschild, Cod. Ms. Karl Schwarzschild 23.1, Sammlung von Photographien, fotografia 14).

51 SUB Göttingen, Nachlass Karl Schwarzschild, Cod. Ms. Karl Schwarzschild 23.1, Sammlung von Photographien, fotografie 14 i 15 . 


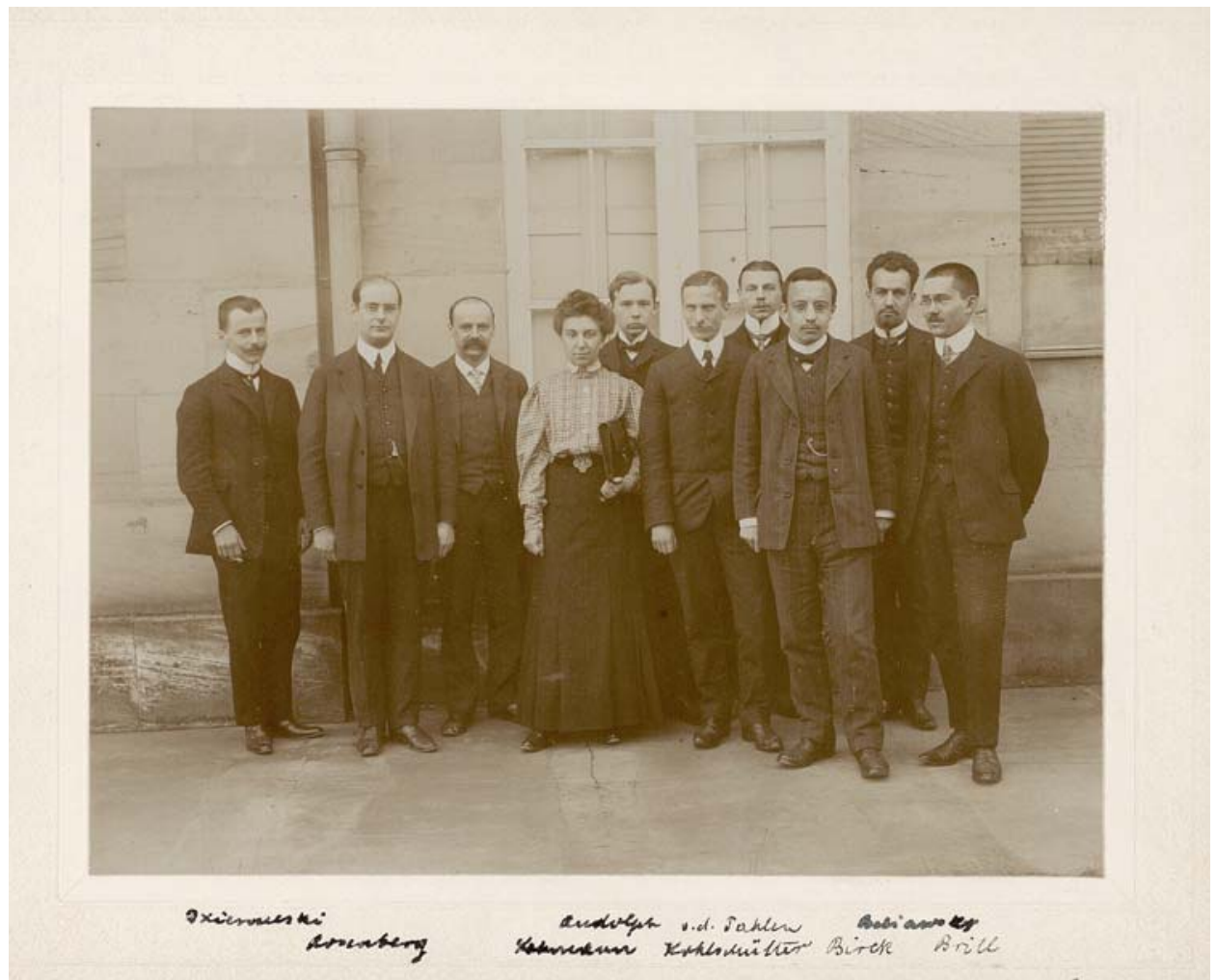

Ryc. 8. Od lewej: Władysław Dziewulski, Hans Rosenberg, Karl Schwarzschild, Ina Lehmann, Karl Rudolph, Emanuel v. d. Pahlen, Arnold Kohlschütter, Otto Birck, Siergiej Iwanowicz Bielawski, Alfred Brill. Getynga, przed Obserwatorium Astronomicznym, przed 1911 r., (SUB Göttingen, Nachlass Karl Schwarzschild, Cod. Ms. Karl Schwarzschild 23.1, Sammlung von Photographien, fotografia nr 15).

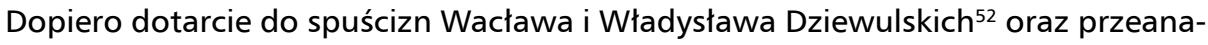
lizowanie danych z archiwum w Getyndze wywołało zaniepokojenie. W spuściznach zdeponowano potwierdzenia studiów odbytych w Getyndze przez Władysława i Wacława. Władysław dwukrotnie zapisywał się na studia ${ }^{53}$. Po raz pierwszy rozpoczął je 16 października 1902 r., w Getyndze pozostał do 11 sierpnia 1903 r. Drugi raz zapisał się na studia 28 października 1907 r., by w kolejnym roku zostać asystentem Karla Schwarzschilda. Wacław również dwukrotnie zapisywał się na studia ${ }^{54}$, pierwszy raz dokonał tego 15 października 1906 r., w Getyndze pozostał do końca roku akademickiego 1910/1911. Władysława latem 1907 r. nie było w Getyndze, Wacław zaś był55. Jasnym stało się, że na zdjęciu znajduje się młodszy z dwóch braci - Wacław. Tę tezę potwierdziła wspólna fotografia braci odnaleziona w ich spuściźnie. Uwieczniony na zdjęciu Wacław nosi gimnazjalny uniform, Władysław zaś mundur studenta 

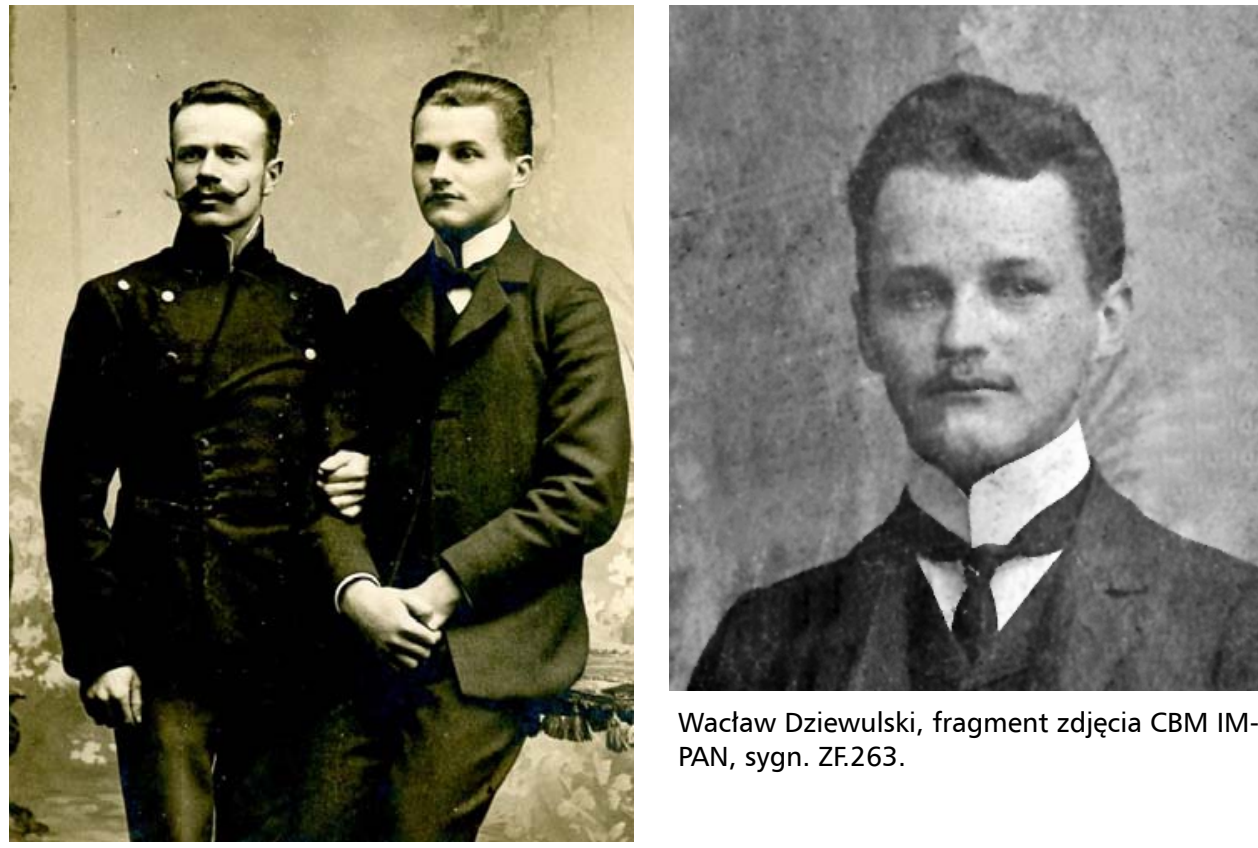

Wacław Dziewulski, fragment zdjęcia CBM IMPAN, sygn. ZF.263.

Ryc. 9. Od lewej: Władysław i Wacław Dziewulscy, ok. 1902 r. (Władysław w mundurze studenta CUW), APAN, III-124, Materiały Wacława Dziewulskiego, j. 8. Fotografie, fot. nr 1;

Cesarskiego Uniwersytetu Warszawskiego, fotografię zatem wykonano około 1902 r. Porównanie zdjęcia obu braci ze zdjęciem grupy polskich studentów i stypendystów daje ostateczną odpowiedź - na zdjęciu ZF.263 sportretowano fizyka Wacława Dziewulskiego.

Błędną identyfikację Wacława Dziewulskiego znajdujemy w publikacjach o Antonim Łomnickim ${ }^{56}$ i pobycie Władysława Orlicza w Getyndze ${ }^{57}$.

Jan Kroo

W tym przypadku identyfikacja postaci na zdjęciu została dokonana prawidłowo. Kłopoty sprawiała forma nazwiska. Samo nazwisko jest prawdopodobnie niderlandzkiego pochodzenia, natomiast krakowska rodzina Kroo wywodziła się z Węgier. Do Il wojny światowej w Krakowie przy ul. Stolarskiej 15 działał kantor Blankstein-Kroo ${ }^{58}$, prowadzony przez Hermanna Kroo, ojca Jana, oraz Emanuela Blanksteina, jego wuja. Jan Kroo urodził się 29 grudnia 1886 r. w Krakowie, gdzie ukończył Gimnazjum im. św. Anny. Po maturze zapisał się na studia fizyczne na Uniwersytecie Wiedeńskim, 
potem na przyrodnicze na Uniwersytecie Georga-Augusta w Getyndze ${ }^{59}$, gdzie pozostawał do 1911 r. W październiku 1912 r. przedstawił na uniwersytecie w Getyndze rozprawę doktorską Zur statistischen Elektronentheorie der Dielektrizität und des Magnetismus, w kolejnym roku został doktorem filozofii ${ }^{60}$. Choć Jan Kroo napisał niewiele prac naukowych, w Polsce mało kto pamięta o jego świetnych rozprawach, w tym o cytowanej do dziś Zur statistischen Elektronentheorie der Dielektrizität und des Magnetismus ${ }^{61}$ oraz o bardzo ciekawym artykule $O$ pewnym twierdzeniu Dynamiki, Über einen Satz der Dynamik ${ }^{62}$. Wróćmy do problemu pisowni jego nazwiska. Wpis w księdze immatrykulacyjnej ma postać „Johann Kroó"63, w pięciu odręcznie sporządzonych dokumentach związanych z postępowaniem doktorskim na Uniwersytecie Georga-Augusta w Getyndze ${ }^{64}$ nazwisko swe Jan pisał bez akcentu. W opublikowanych przez niego artykułach nazwisko pojawia bez akcentu, ale także w wersjach „Kroó” oraz „Kroò”. Można zatem przyjąć, że są to trzy poprawne formy jego nazwiska. Niepoprawne formy z jakimi można się zetknąć to „Króo”, „Kroć” oraz „Król”. Ten ostatni błąd pojawił się w ciągu kilku ostatnich lat i w moim przekonaniu jest rezultatem autokorekty wykonanej przez program do edycji tekstu. $Z$ tego powodu nie był obiektem badań.

Pierwsza z błędnych form jego nazwiska - „Króo” - rozpowszechniła się w rezultacie książkowej publikacji Wspomnień i zapisków Steinhausa. Czytamy tam: „Nie byli to jedyni Polacy w Getyndze; studiowali tam [...] fizyk Jan Króo, Sokołowski, matematyk Żyliński, Szadurski, antropolog Edward Loth i wielu innych"65. Taka sama forma nazwiska Jana znajduje się w kolejnych wydaniach (polskim ${ }^{66}$ i angielskim ${ }^{67}$ ) Wspomnień i zapisków. W maszynopisie wspomnień błędu nie ma68; nie ma również w wydanych przez „Znak” Wspomnieniach Steinhausa; tam czytamy: „Nie byli to jedyni Polacy w Getyndze; studiowali tam [...] fizyk Jan Kroo, Sokołowski, matematyk Żyliński, Szadurski, antropolog Edward Loth i wielu innych"69. Ten sam błąd znajduje się w opisie zdjęcia ZF.263. Trudno orzec, czy to on był powodem pojawienia się błędu w londyńskim wydaniu wspomnień Steinhausa.

59 UniA Gö, Matricula studiosorum in Academia Georgicae Augusta, 1906, Michaelis, poz. 68. Data wpisu 7 października $1906 \mathrm{r}$.

60 O postępowaniu doktorskim i zgromadzonych dokumentach szerzej w: D. Ciesielska, L. Maligranda, J. Zwierzyńska, Doktoraty Polaków w Getyndze. Matematyka, „Analecta” t. 28, 2019, nr 2, s. 73-116.

61 J. Kroo, Zur statistischen Elektronentheorie der Dielektrizität und des Magnetismus, „Annalen der Physik” t. 42, 1913, s. 1354-1396.

62 Idem, O pewnym twierdzeniu Dynamiki. - Uber einen Satz der Dynamik „,Bulletin international de l'Académie des sciences de Cracovie. Classe des sciences mathématiques et naturelles, Sér. A, Sciences mathématiques" 1917, s. 266-268, Pracę tę przedstawił na posiedzeniu III Wydziału Akademii dnia 8 października 1917 r. Władysław Natanson. Recenzję pracy do czasopisma referencyjnego "Jahrbuch über die Fortschritte der Mathematik" napisał krakowski matematyk i fizyk matematyczny Alfred Rosenblatt, również student Uniwersytetu GeorgaAugusta w Getyndze.

63 UniA Gö, Matricula studiosorum in Academia Georgicae Augusta, 1906, Michaelis, poz. 68. Data wpisu 7 października $1906 \mathrm{r}$.

64 UniA Gö, Prom. Spec. K 1912-1915, nr 10, dokumenty doktorskie Jana Kroo, 10 k.

65 H. Steinhaus, Wspomnienia i zapiski, Londyn 1992, s. 40, powtórzone na s. 88.

66 Idem, Wspomnienia i zapiski, Wrocław 2002.

67 Idem, Mathematician for All Seasons: Recollections and Notes, vol. 1, 1887-1945, red. R.G. Burns, I. Szymaniec, A. Weron, New York 2015, s. 53.

68 APAN, III-204, Materiały Hugona D. Steinhausa, Wspomnienia, fragment do $1920 \mathrm{r}$.

69 H. Steinhaus, Wspomnienia, s. 79. 
Druga z błędnych form pojawiła się w książce Romana Kałuży o Stefanie Banachu ${ }^{70}$. Czytamy: „Odtąd spotykaliśmy się regularnie, a że wtedy był w Krakowie Władysław Ślebodziński, Leon Chwistek, Jan Kroć i Włodzimierz Stożek, postanowiliśmy założyć towarzystwo matematyczne"71. Błąd został powtórzony w angielskim tłumaczeniu tej książki72 wydanym przez renomowane wydawnictwo Birkhäuser. Przywołany fragment jest cytatem z wydanych przez „Znak" Wspomnień Steinhausa, ale tam błędu nie ma. Warto zaznaczyć, że ta błędna forma nazwiska podana jest też w wykazie maturzystów Gimnazjum św. Anny w Krakowie ${ }^{73}$. Wątpliwe jest jednak, by z tej pozycji Kałuża korzystał. W polskim wydaniu książki Kałuży znajdują się literówki w nazwiskach, np. Steinhaus figuruje jako „Steinhas”, „Steihaus” i „Stenhaus”74. W angielskim wydaniu tej książki większość z nich została skorygowana, ale nie wszystkie.

\section{Podsumowanie}

W tym krótkim artykule przedstawiono zaledwie mały wycinek badań prowadzonych w ramach projektu, którego jednym z głównych celów jest zebranie i przedstawienie rzetelnych informacji na temat studiów i pobytów stypendialnych polskich uczonych w mekce matematyków, czyli w Getyndze, w okresie 1885-1933. Historia jednego zdjęcia, które stanowi ważną pamiątkę dla polskiej nauki, a było już wcześniej znane i wykorzystywane, pokazuje, jak trudnego zadania się podjęliśmy.

\section{Bibliografia}

\section{Źródła archiwalne}

Archiwum Uniwersytetu Jagiellońskiego [AUJ]:

sygn. DC, spuścizna Tadeusza Banachiewicza;

WF II 103, Fundacja Kazimierza Klimkowskiego 1889-1939.

Archiwum Polskiej Akademii Nauk [APAN]:

III-204, Materiały Hugona D. Steinhausa;

III-124, Materiały Wacława Dziewulskiego;

III-148, Materiały Władysława Dziewulskiego.

Archiwum Matematyków w IMPAN, CBM IMPAN, sygn. ZF.263.

Biblioteka Główna Uniwersytetu Pedagogicznego w Krakowie, spuścizna T. Banachiewicza.

70 R. Kałuża, Stefan Banach, Warszawa 1992.

71 Ibid., s. 41.

72 Idem, Through a Reporter's Eyes. The life of Stefan Banach, tłum. i red. A. Konstant, W. Woyczyński, Boston Basel - Berlin 1995, s. 23.

73 Z dziejów liceum Nowodworskiego w Polsce Ludowej, Kraków 1963.

74 Więcej przykładów w recenzji: K. Ciesielski, R. Kałuża, Stefan Banach, „Wiadomości Matematyczne” t. 30, 1993 , nr 1, s. 144-147. 
Niedersächsische Staats- und Universitätsbibliothek Göttingen [SUB Göttingen]:

Nachlass Karl Schwarzschild, Cod. Ms. Karl Schwarzschild 23.1, Sammlung von Photographien;

Nachlass Felix Klein, Cod. Ms. F. Klein 7E., Hörerverzeichnisseder Vorlesungen F. Kleins 1871-1920.

Universitätsarchiv Göttingen [UniA Gö]:

Matricula in studiosorum Academia Georgicae Augusta, lata 1885-1933;

Amtliches Verzeichnis des Personals und der Studierenden der Königl. Georg-AugustUniversität zu Göttingen, lata 1884-1933,

Prom. Spec. K 1912-1915, nr 10, dokumenty doktorskie Jana Kroo.

\section{Źródła drukowane}

Krakowska Księga Adresowa, Kraków 1907.

Kempinsei [Kępiński] S., Ueber Fuchs'sche Functionen zweier Variabeln, „Mathematische Annalen" 1896, t. 47, nr 4, s. 573-588, DOI 10.1007/BF01445803.

Kroo J., O pewnym twierdzeniu Dynamiki. - Uber einen Satz der Dynamik, „Bulletin international de l'Académie des sciences de Cracovie. Classe des sciences mathématiques et naturelles, Sér. A, Sciences mathématiques" 1917, s. 266-268.

Kroo J., Zur statistischen Elektronentheorie der Dielektrizität und des Magnetismus, „Annalen der Physik" t. 42, 1913, s. 1354-1396, DOI 10.1002/andp.19133471620.

Pšeborskij [Przeborski] A.P., Otčet o zagraničnoj komandirovk" privat'-docenta A.P. Pšeborskago, „Zapiski Imperatorskago Har'kovskogo Universiteta” t. 1, 1906, s. 26-34.

\section{Literatura przedmiotu}

Ciesielska D., Maligranda L., Zwierzyńska J., Doktoraty Polaków w Getyndze. Matematyka, „Analecta" t. 28, 2019, nr 2, s. 73-116.

Ciesielska D., Stypendyści Akademii Umiejętności i Uniwersytetu Jagiellońskiego na Uniwersytecie Georga-Augusta w Getyndze w latach 1891-1914. Matematyka, "Studia Historiae Scientiarum" t. 19, 2020, s. 375-322, DOI 10.4467/2543702XSHS.20.012. 12568.

Ciesielski K., R. Kałuża, Stefan Banach, „Wiadomości Matematyczne” t. 30, 1993, nr 1, s. 144-147.

Słownik biograficzny matematyków polskich, red. S. Domoradzki, Z. Pawlikowska-Brożek, D. Węglowska, Tarnobrzeg 2003.

Dénes T., Real face of János Bolyai, „Notices of the American Mathematical Society” t. 58, 2011, nr 1, s. 41-51.

Duda R., Matematycy XIX i XX wieku związani z Polską, Wrocław 2012.

Duren P., Changing Faces: The Mistaken Portrait of Legendre, "Notices of the American Mathematical Society" t. 56, 2009, nr 11, s. 1440-1443.

Dybiec J., Finansowanie nauki i oświaty w Galicji 1860-1918, Kraków 1979.

Władysław Dziewulski (1878-1962), red. C. Iwaniszewska, Warszawa - Poznań - Toruń 1978.

Kałuża R., Stefan Banach, Warszawa 1992.

Kałuża R. Through a Reporter's Eyes. The life of Stefan Banach, red. i tłum. A. Konstant, W. Woyczyński, Boston - Basel - Berlin 1995. 
Kijas A., Polacy na Uniwersytecie Charkowskim 1805-1917, Poznań 2005.

Maligranda L., Antoni Łomnicki (1881-1941), „Wiadomości Matematyczne” t. 44, 2008, nr 1, s. 61-112, DOI 10.14708/wm.v44i01.5088.

Maligranda L., Władysław Orlicz w Getyndze: 1928-1930, „Wiadomości Matematyczne” t. 54, 2018, nr 2, s. 191-219.

Maślanka K., Zamieniony portret i fikcyjna stała matematyczna. Adrien-Marie Legendre po latach, „Kwartalnik Historii Nauki i Techniki” t. 55, 2010, nr 2, s. 69-84.

Olesiak Z.S., Profesor Antoni Przeborski (1871-1941), „Kwartalnik Historii Nauki i Techniki" t. 46, 2001, nr 3, s. 125-132.

Pawlikowska-Brożek Z., Sękowska M., Węglowska D., Archiwum Matematyczne w Sopocie, „Kwartalnik Historii Nauki i Techniki” t. 38, 1993, nr 1, s. 121-136.

Sawicki J., Wróblewski A.K., Jak Józef Herman Osiński został obdarzony obliczem lorda Kelvina. Proces poszlakowy, „Kwartalnik Historii Nauki i Techniki” t. 64, 2019, nr 2, s. 45-60, DOI 10.4467/0023589XKHNT.19.013.10343.

Steinhaus H., Mathematician for All Seasons: Recollections and Notes, vol. 1, 1887-1945, red. R.G. Burns, I. Szymaniec, A. Weron, New York 2015, DOI 10.1007/978-3-319-21984-4.

Steinhaus H., Wspomnienia, „Znak” 1970, nr 1, s. 42-106.

Steinhaus H., Wspomnienia i zapiski, Londyn 1992.

Steinhaus H., Wspomnienia i zapiski, Wrocław 2002.

Tatarkiewicz K., Matematyk, a nie mechanik (Antoni Przeborski), [w:] Matematycy polskiego pochodzenia na obczyźnie. Materiały z XI Ogólnopolskiej Szkoły Historii Matematyki, Kołobrzeg, 5-9 maja 1997, red. Stanisław Fudali, Szczecin 1998, s. 143-160.

Z dziejów liceum Nowodworskiego w Polsce Ludowej, Kraków 1963.

\section{Druki ulotne}

Ciesielska D., Maligranda L., Zwierzyńska J., Obrazy z historii Polskiej nauki. Matematycy, fizycy $i$ astronomowie na Uniwersytecie w Getyndze (1895-1933), wystawa plakatów na „Jubileuszowym Zjeździe Matematyków w stulecie PTM”, Kraków 2019.

\section{Finansowanie}

Artykuł powstał $w$ ramach projektu badawczego Studia $i$ badania naukowe polskich matematyków, fizyków i astronomów na Uniwersytecie w Getyndze (1895-1933) finansowanego przez Narodowe Centrum Nauki w ramach programu OPUS-13, nr umowy UMO-2017/25/B/HS3/02420.

dr Danuta Ciesielska, historyk nauki. Uzyskała doktorat nauk matematycznych na UJ, specjalizuje się w historii matematyki XIX i XX w. Szczególnie interesują ją dokonania matematyków polskich, a także krajowe i międzynarodowe instytucje i organizacje zrzeszające matematyków oraz historia geometrii rzutowej i algebraicznej. Jest adiunktem w Instytucie Historii Nauki im. L. i A. Birkenmajerów PAN, członkiem Komisji Historii Nauki PAU.

e-mail: smciesie@cyfronet.krakow.pl

Data zgłoszenia artykułu: 10 lutego 2020

Data przyjęcia do druku: 3 maja 2020 